JMEMME (Journal of Mechanical Enggineering, Manufactures, Materials and

Energy), Vol. 3 (01) Juni (2019) p-ISSN: 2549-6220e-ISSN: 2549-6239

Doi: 10.31289/imemme.v3i1.2499

JMEMME (Journal of Mechanical Engineering, Manufactures, Materials and Energy)

Available online http://ojs.uma.ac.id/index.php/jmemme

\title{
RANCANGAN MEDIA ADSORBSI ZEOLIT ALAM SEBAGAI ADSORBEN EMISI GAS MESIN OTOMOTIF
}

\section{DESIGN OF ADSORPTION MEDIA FOR NATURAL ZEOLITE AS AN ADSORBENT AUTOMOTIVE ENGINE GAS EMISSIONS}

\author{
Amru Siregar ${ }^{1)^{*} *}$, Amirsyam Nasution ${ }^{1)}$, dan Mustafa ${ }^{2)}$ \\ 1) Program Studi Teknik Mesin, Universitas Medan Area, Indonesia \\ 2) Jurusan Teknik Kimia, Institut Teknologi Medan, Indonesia \\ Diterima: 03-05-2019 ; Disetujui: 25-06-2019 ; Diterbitkan: 30-06-2019 \\ *Corresponding author: srgamru@gmail.com
}

\begin{abstract}
Abstrak
Bahan bakar fosil merupakan sumber energi utama untuk aktivitas industri, transportasi, produksi listrik dan kegiatan pertambangan. Emisi gas hasil pembakaran bahan bakar fosil secara teoritis mengandung polutan emisi gas yang terdiri dari gas-gas $\mathrm{CO}_{\mathrm{x}}, \mathrm{NO}_{\mathrm{x}}, \mathrm{HC}, \mathrm{O}_{\mathrm{x}}, \mathrm{SO}_{2}$ dan logam-logam berat. Pembakaran bahan bakar fosil pada sektor transportasi berkontribusi paling besar terhadap polusi yang dihasilkan oleh emisi gas buang mesin otomotif. Oleh karena itu perlu dilakukan penanganan yang tepat terhadap emisi gas mesin otomotif ini. Hal ini telah dirancang bentuk geometris alat yang berfungsi sebagai media adsorbsi emisi gas mesin otomotif yang disebut bed reactor (BR). Bentuk geometris dari BR dirancang merujuk kepada bentuk geometris dari knalpot (muffler) kenderaan mobil mini bus. BR yang dirancang terdiri dari 2 (dua) jenis BR yaitu jenis aliran laminar dan aliran turbulen. Bentuk geometris BR, berbentuk penampang elips dengan sumbu mayor $=192 \mathrm{~mm}$, sumbu minor $=125 \mathrm{~mm}$, dan panjang muffler $=320 \mathrm{~mm}$, untuk jenis aliran laminar. Sedangkan BR jenis aliran turbulen berbentuk penampang elips dengan sumbu mayor $192 \mathrm{~mm}$ dan sumbu minor $125 \mathrm{~mm}$, dan panjang muffler $\mathrm{L}=350$ $\mathrm{mm}$. Daya adsorbsi BR telah diuji dengan bantuan alat uji emisi gas jenis anycar autochek gas \& smoke versi 1.5.1.E-1. Daya adsorbsi BR maksimum untuk jenis aliran laminar terhadap gas $\mathrm{CO}_{2}=47,76 \%$ dan untuk aliran turbulen $\mathrm{CO}=42,72 \%$ \& gas $\mathrm{HC}=35,40 \%$, masing-masing $\mathrm{BR}$ diisi zeolit alam dengan besar butir 10 mesh.
\end{abstract}

Kata Kunci: bed reactor, zeolit alam, adsorpsi, emisi gas

\begin{abstract}
Fossil fuels are the main energy source for industrial activities, transportation, electricity production and mining activities. Gas emissions from burning fossil fuels theoretically contain gas emission pollutants consisting of COx, $\mathrm{NOx}, \mathrm{HC}, \mathrm{Ox}, \mathrm{SO} 2$ and heavy metals gases. The burning of fossil fuels in the transportation sector contributes most to the pollution generated by automotive engine exhaust emissions. Therefore, it is necessary to handle the gas emissions of automotive engines. This has been designed a geometric shape of a tool that serves as a medium for adsorption of automotive engine gas emissions called the bed reactor (BR). The geometric shape of the BR is designed to refer to the geometric shape of the muffler of a mini bus. The designed BR consists of 2 (two) types of BR, namely the type of laminar flow and turbulent flow. The geometric shape of the BR, in the form of an elliptical cross section with a major axis $=192 \mathrm{~mm}$, a minor axis $=125 \mathrm{~mm}$, and a length of muffler $=320 \mathrm{~mm}$, for the type of laminar flow. While the turbulent flow type BR is an elliptical cross section with a major axis of $192 \mathrm{~mm}$ and a minor axis of $125 \mathrm{~mm}$, and a length of muffler
\end{abstract}


$L=350 \mathrm{~mm}$. The adsorption capacity of the BR has been tested with the help of anycar emission gas type test equipment, autochek gas \& smoke version 1.5.1.E-1. The maximum BR adsorption power for laminar flow towards $\mathrm{CO} 2=47.76 \%$ and for turbulent flow $\mathrm{CO}=42.72 \%$ \& $\mathrm{HC}$ gas $=35.40 \%$, each BR is filled with natural zeolite with 10 mesh grains.

Keywords: bed reactor, natural zeolite, adsorption, gas emissions

How to Cite: Siregar, A., 2019, Rancangan Media Adsorbsi Zeolit Alam Sebagai Adsorben Emisi Gas Mesin Otomotif, JMEMME (Journal of Mechanical Enggineering, Manufactures, Materials and Energy), 3(01): 6475 


\section{PENDAHULUAN}

Pertambahan penduduk, urbanisasi dan kemajuan teknologi merupakan faktor-faktor pendorong peningkatan pemakaian bahan bakar fosil dengan cepat. Bahan bakar fosil merupakan sumber energi utama untuk aktivitas industri, transportasi, produksi listrik dan kegiatan pertambangan. Secara teori emisi gas buang hasil pembakaran bahan bakar fosil mengandung polutan emisi gas yang terdiri dari gas-gas $\mathrm{CO}_{x}, \mathrm{NO}_{\mathrm{x}}, \mathrm{HC}$, $\mathrm{O}_{\mathrm{x}}, \mathrm{SO}_{2}$ dan logam berat lainnya. Polutan emisi gas tersebut memberikan kontribusi pada pemanasan global, efek rumah kaca, dan perubahan iklim. Selain hal ini berpengaruh kepada perubahan kondisi alam, emisi gas buang juga berpengaruh kepada kehidupan mahluk hidup, karena emisi gas asap tersebut akan bergerak dengan cepat ke berbagai tempat. Baik manusia maupun hewan akan menyerap gas CO melalui paruparu, dimana gas CO ini jika bereaksi dengan haemoglobin dalam darah akan membentuk karbon monoksida haemoglobin (COHb). Haemoglobin mempunyai sifat kemampuan yang tinggi untuk mengikat gas $\mathrm{CO}$, jauh lebih besar dari pada kemampuan untuk mengikat gas oksigen $\left(\mathrm{O}_{2}\right)$, sehingga keberadaan gas $\mathrm{CO}$ ini di dalam darah dapat mencegah pendistribusian oksigen oleh darah ke seluruh tubuh, yang mengakibatkan gangguan pada jantung

Emisi gas asap di bidang transportasi berkontribusi terbesar terhadap polusi udara dibandingkan dengan sumber emisi gas lainnya, terutama dihasilkan oleh mesin otomotif jenis motor bakar otto. Emisi gas buang mesin otomotif di kota-kota besar, berkontribusi sebagai sumber polutan emisi gas mencapai $(60 \div 70) \%$, sementara kontribusi emisi gas dari cerobong asap industri hanya berkisar $(10 \div 15) \%$, sedangkan sisanya berasal dari sumber pembakaran lainnya, (Ismiyati, dkk. 2014). Oleh karena itu diperlukan perhatian dan penanganan yang tepat serta berkesinambungan dalam menanggulangi emisi gas buang tersebut. Secara teori metode-metode untuk mengurangi polutan emisi gas buang mesin otomotif dinyatakan sebagai berikut ini : (a). Mengembangkan substitusi bahan bakar dengan tujuan untuk mengurangi polutan. (b) Mengembangkan sumber energi terbarukan. (c) Memodifikasi mesin untuk mengurangi jumlah polutan yang terbentuk. (d) Mengembangkan penggunaan catalytic converter. (e) Memperbaiki sistem pengapian, dan (f) Meningkatkan perawatan kendaraan bermotor.

Pengembangan sistem penanggulangan emisi gas buang telah banyak diteliti oleh beberapa peneliti terdulu, khususnya tentang penggunaan sumber daya alam. Mineral zeolit merupakan salah satu sumber daya alam yang telah banyak diteliti, oleh karena mineral ini banyak dijumpai di bumi Indonesia, (Kusdarto, 2018). Mineral zeolit alam terdiri dari oksida-oksida, $\mathrm{A}_{2} \mathrm{O}_{3}, \quad \mathrm{SiO}_{2}, \mathrm{Fe}_{2} \mathrm{O}_{3}, \mathrm{CaO}$ dan $\mathrm{MgO}$. Sebagian dari penyusun mineral zeolit ini terdapat dalam batuan-batuan sedimen, terutama kristal- kristal dari kelompok alumina dan silikat. Zeolit alam dapat diaplikasikan sebagai absorben, penukar ion, dan sebagai katalis, sehingga jenis mineral ini banyak 
digunakan dalam bidang-bidang; industri, pertanian, peternakan maupun lingkungan hidup, (Tsishvili,1992). Zeolit alam juga telah banyak digunakan sebagai katalis, pengisi kertas, cat, bahan semen pozolan dan portland, agregat ringan, pupuk, pencegah polusi akibat limbah industri, penyerap dalam proses pemurnian pada pembuatan gas-gas, seperti oksigen, nitrogen, methana dan pengikat ammoniak, (Sarno, 1983). Zeolit alam yang telah diaktivasi mampu mengadsorbsi gas $\mathrm{CO}$ dari emisi gas asap kebakaran sebesar 6,25 \%, (Yuliusman, dkk., 2010), dan 3,67 \% (Suraputra, 2011). Daya adsorpsi zeolit alam untuk gas $\mathrm{CO}_{2}$ pada proses produksi biogas adalah 3,80 \% untuk besar butir 60 mesh, (Yamliha, dkk., 2013). Pada proses dehidrasi boietanol dapat digunakan zeolit alam yang telah dimodifikasi dengan proses acidifikasi dan pengkayaan ion $\mathrm{Al}^{+3}$ (Khaidir, dkk., 2009). Hasil aktivasi zeolit alam dengan $\mathrm{HF} 2 \%, \mathrm{HCl} 6 \mathrm{M}$, dan $\mathrm{NH}_{4} \mathrm{Cl}$ 0,1 M, yang dikuti dimodifikasi dengan $\mathrm{TiO}_{2}$ dapat mereduksi gas $\mathrm{NO}_{2}$ sekitar $(45 \div 49) \%$ dari emisi gas buang kenderaan bermotor, (Hasibuan, 2012). Sedangkan aktivasi zeolit alam dengan asam $\mathrm{HCl}$ yang konsentrasinya bervariasi, berpengaruh daya absorsinya terhadap $\mathrm{Ca}^{2+}$ (Pardoyo, dkk., 2009). Sistem adsorbsi emisi gas mesin otomotif yang disebut reduction chamber (RC), telah dirancang oleh Venkatesh, dkk., (2016). Komponen-komponen dari RC ini terdiri rongga silindris dengan diameter 100 $\mathrm{mm}$ dan panjang $300 \mathrm{~mm}$. Rongga silindris ini diselimuti dengan susunan jaringan kawat (wire mesh), sehingga penampang silindris mempunyai rongga yang porous.

Pada paper ini menguraikan hasil rancangan suatu alat yang berfungsi sebagai media adsorbsi emisi gas buang mesin otomotif oleh zeolit alam sebagai adsorben yang dipasangkan pada knalpot mesin otomotif. Dalam hal ini alat tersebut selanjutnya disebut dengan bed reactor (BR). Uraian rancangan ini merinci pemilihan bentuk geometris dari $\mathrm{BR}$, sehingga diharapkan hasil rancangan ini dapat memberikan kontribusi terhadap pengurangan polutan emisi gas buang mesin otomotif. Polutan emisi gas buang yang diserap BR diukur dengan alat uji emisi gas buang jenis anycar autochek gas \& smoke versi 1.5.1.E-1. Alat uji emisi gas ini dapat mendeteksi gas-gas; $\mathrm{CO}, \mathrm{CO}_{2}$, dan $\mathrm{HC}$ yang dikandung oleh emisi gas buang.

\section{METODE}

\section{Pengolahan Adsorben}

Sebagai adsorben pada penelitian ini adalah zeolit alam dan bentuk butiran. Pada awalnya zeolit alam mentah diolah secara proses fisika. Batuan zeolit alam dipecah dan digiling hingga diperoleh butiran-butiran zeolit. Butiran-butiran zeolit ini diayak sehingga diperoleh besar butiran 10 mesh, dan 20 mesh. Selanjutnya butiran-butiran zeolit ini dipanaskan di dalam tanur pemanas sampai temperatur $300^{\circ} \mathrm{C}$ dan ditahan selama 3 jam. Pada tahapan berikutnya dilakukan proses dealuminasi zeolit alam yaitu dengan cara pengasaman. Butiran zeolit alam direndam dalam larutan $\mathrm{HCl}$ dengan konsentrasi 2M, selama 2 jam. Kemudian dilanjutkan pencucian dengan akuades, sampai 
diperoleh filtrat menunjukkan $\mathrm{pH}$ netral. Residu butiran zeolit ini dikeringkan melalui pemanasan dalam tanur pemanas sampai temperatur $300^{\circ} \mathrm{C}$ dan ditahan selama 3 jam. Butiran zeolit alam yang dihasilkan pada proses terakhir ini merupakan butiran zeolit alam yang telah aktif.

\section{Rancangan Bed Reactor}

Alat yang berfungsi sebagai media adsorbsi oleh butiran zeolit alam terhadap emisi gas buang mesin otomotif disebut dengan bed reactor (BR). Rancangan BR diawali dengan pemilihan bentuk geometris. Pemilihan bentuk geometris BR mempertimbangkan 2 (dua) hal, yaitu bentuk bangun BR dan dimensi BR itu sendiri. Dalam hal ini bentuk bangun dan dimensi BR ditentukan berpedoman kepada bentuk knalpot (muffler) mesin otomotif jenis kenderaan mini bus secara umum. Hal ini disebabkan oleh karena kenderaan mini bus diambil sebagai objek penelitian. Hasil pemilihan bentuk dan dimensi BR diperlihatkan pada gambar 1 dan gambar 2 untuk BR jenis aliran laminar, sedangkan gambar 3 dan gambar 4 untuk BR jenis aliran turbulen. Penyerapan polutan emisi gas buang akan terjadi jika aliran emisi gas buang mesin otomotif bersentuhan dengan permukaan butiran-butiran zeolit. Semakin besar permukaan sentuh antara emisi gas dengan butiran zeolit maka akan semakin jumlah polutan emisi gas yang teradsorpsi. Agar keadaan ini dapat terjadi maka dibuatlah bed reactor ini memiliki laluan gas asap berbentuk pipapipa. Di dalam pipa ini diletakkan bolabola berongga. Bola-bola berongga diisi dengan butiran zeolit yang telah diaktifkan. Oleh karena bola-bola diberi lubang-lubang laluan emisi gas buang yang bentuk lingkaran. Lubang-lubang laluan emisi gas ini ditutup dengan jalajala kawat, sehingga butiran-butiran zeolit tidak dapat keluar dari dalam bola gambar 5. Ketika pipa-pipa BR ini dialiri emisi gas buang bertekanan, maka bolabola berjaring ini akan dapat bergelinding akibat dorongan emisi gas. Keadaan ini meyebabkan butiran zeolit yang berada di dalam bola berjaring tersebut ikut berputar. Akibat perputaran butiran zeolit dan ditambah dengan turbulensi aliran emisi gas bertekanan, maka akan semakin besar kemungkinan adsorbsi polutan emisi gasbuang oleh butiran zeolite.

\section{Pengujian Daya Adsorbsi}

Sebagai data pembanding terlebih dahulu diukur komposisi emisi gas buang mesin otomotif tanpa memakai alat BR. Dengan demikian diperoleh persentasi (\%) gas-gas $\mathrm{CO}, \mathrm{CO}_{2}$, dan $\mathrm{HC}$ yang terkandung di dalam emisi gas buang mesin otomotif tersebut. Tahap berikutnya adalah pemasangan alat BR pada ujung knalpot mesin otomotif tersebut 'dan selanjutnya dilakukan pengukuran komposisi emisi gas yang keluar dari ujung BR tersebut. Hal ini dilakukan baik untuk BR jenis aliran laminar maupun untuk jenis aliran turbulen, sehingga diperoleh komposisi emisi gas yang keluar dari ujung pipa BR. Selain bentuk geometri BR, besar butir zeolit juga merupakan variabel dalam pengujian ini. Selanjutnya komposisi emisi gas buang mesin otomotif tanpa memakai alat BR, dan komposisi emisi 
gas yang memakai alat $\mathrm{BR}$, ditampilkan pada tabel 1, tabel 2, dan tabel 3 .

\section{HASIL DAN DISKUSI \\ Hasil Rancangan BR}

Alat media adsorbsi oleh zeolit alam terhadap emisi gas yang keluar dari knalpot mesin otomotif disebut dengan bed reactor (BR). Gambar 1 dan gambar 2 menunjukkan penampang BR jenis aliran laminar. Gambar 3 dan gambar 4, menunjukkan penampang BR jenis aliran turbulen. Pada pemakaiannya, BR dipasangkan pada ujung knalpot (muffler) mesin otomotif sedemikian rupa sehingga emisi gas buang yang dikeluarkan oleh mesin otomotif dapat mengalir di dalamnya. BR tersebut memiliki dua pipa saluran emisi gas buang, dimana setiap pipa masingmasing berisi 3 (tiga) buah bola berongga yang berjaring kawat, seperti diperlihatkan pada gambar 5. Bola-bola berongga ini diisi dengan butiran zeolit sebagai adsorben. Emisi gas yang mengalir di dalam pipa akan masuk ke dalam bola-bola berongga dan bersentuhan dengan butiran zeolit. Emisi gas yang keluar dari knalpot mesin otomotif mempunyai tekanan dan kecepatan, akibatnya emisi gas ini dapat menyebabkan bola berguling, sehingga aliran emisi gas di dalam rongga bola menjadi aliran turbulensi. Adanya aliran turbulensi ini memungkinkan persentuhan permukaan butiran-butiran zeolit dengan emisi gas semakin besar. Oleh karena adanya persentuhan emisi gas dengan butiran zeolit maka akan terjadi penyerapan atau adsorpsi gas-gas yang terkandung di dalam emisi gas tersebut. Polutan emisi gas yang dapat dideteksi adalah gas $\mathrm{CO}, \mathrm{CO}_{2}$, dan $\mathrm{HC}$.

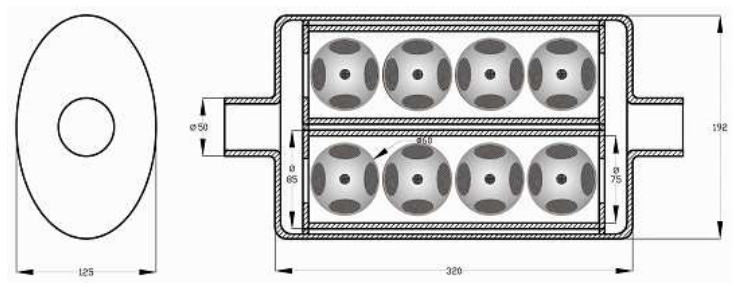

Gambar 1. Sket penampang bentuk geometris BR jenis aliran laminar

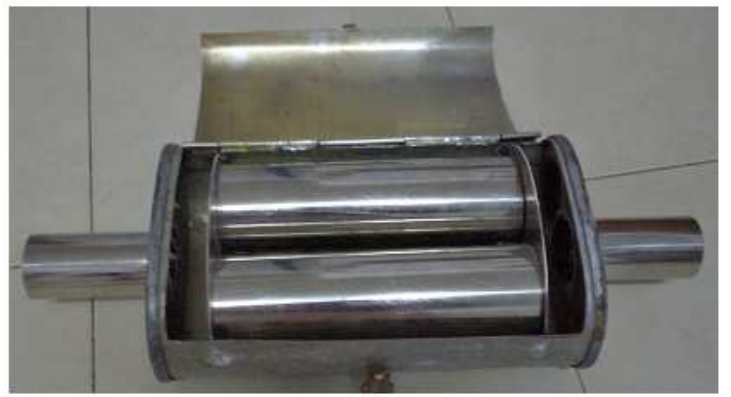

Gambar 2. Tampak bagian dalam bentuk geometris BR jenis aliran laminar

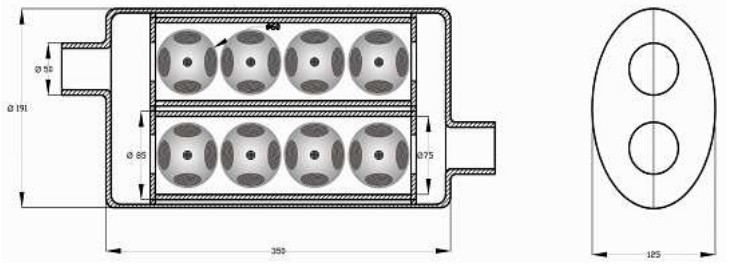

Gambar 3. Sket penampang bentuk geometris BR jenis aliran turbulen

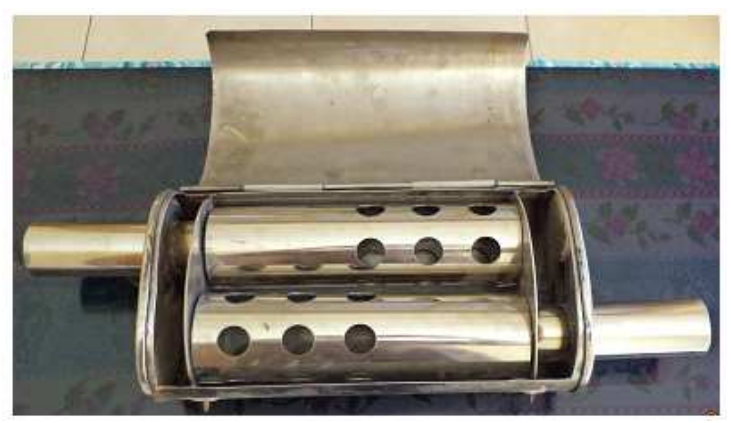

Gambar 4. Tampak bagian dalambentuk geometris BR jenis aliran turbulen 


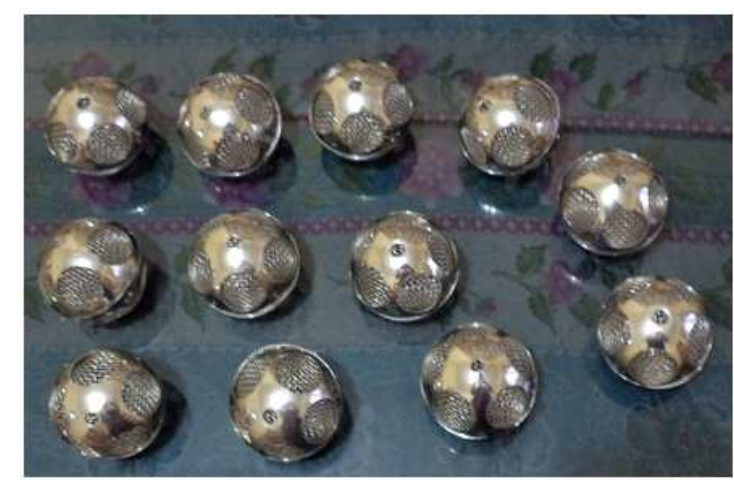

Gambar 5. Bola-bola berjaring

Perancangan BR merupakan pemilihan bentuk geometris dari BR itu sendiri. Prinsip dari perancangan BR adalah memilih bentuk bangun dan dimensi yang optimum. Pemilihan bentuk geometris BR merujuk kepada bentuk geometris knalpot (Muffler) mesin mobil minibus secara umum. Selain bentuk geometris, faktor daya adsorbsi (adsorption) juga harus dipertimbamgkan. BR yang diinginkan memiliki daya adsorbsi terhadap polutan emisi gas buang semaksimal mungkin. Knalpot (muffler) pada kenderaan roda empat jenis minibus memiliki dimensi panjang $\pm(300 \div 500) \mathrm{mm}$ dengan penampang bentuk elips. Berpedoman pada data ini, maka dipilihlah bentuk geometris BR ini sebagai berikut. Panjang muffler $\mathrm{L}=320 \mathrm{~mm}$ dengan bentuk penampang elips. Bentuk kontur elip mempunyai sumbu mayor $=192 \mathrm{~mm}$ dan sumbu minor $=125 \mathrm{~mm}$ untuk BR jenis aliran laminar. Sedangkan untuk jenis aliran turbulen panjang muffler $\mathrm{L}=$ $350 \mathrm{~mm}$, dengan bentuk penampang elips. Penampang elips memilki panjang sumbu mayor $192 \mathrm{~mm}$ dan sumbu minor $125 \mathrm{~mm}$. Pada rongga BR ini diletakkan dua buah pipa berdiameter 3"(tiga inchi). Masing-masing pipa tersebut diisi 4 (empat) buah bola berjaring. Karena BR mempunyai dua pipa saluran, maka BR berisi delapan bola berjaring. Bola berjaring mempunyai diameter $60 \mathrm{~mm}$ dan diisi dengan butiran zeolit sampai $3 / 4$ bagian dari volume bola, maka setiap bola berjaring harus diisi butiran zeolit sebanyak $\mathrm{v}=3 / 4 \times 4 / 3(\pi)(30)^{3} \approx 85 \mathrm{~cm}^{3}$. Jika berat jenis zeolit alam 1,2 maka berat zeolit alam setiap bola berisi $\mathrm{m}=85$ $\mathrm{x} 1,2=102$ gram. Dengan demikian setiap BR diisi zeolit alam sebanyak $\mathrm{M}=$ $8 \times 102$ gram = 816 gram .

Pada tabel 1 diperlihatkan 25 (dua puluh lima) data sampel pengujian daya adsorbsi dari BR jenis aliran laminar dan aliran turbulen terhadap gas CO untuk besar butir 10 mesh dan 20 mesh. Kemudian data-data tersebut disajikan juga dalam bentuk kurva seperti ditunjukkan pada gambar 6 dan gambar 7. Dari tabel 1 dapat dilihat bahwa nilai rerata daya adsorbsi BR jenis aliran laminar relatif sama dengan nilai ratarata daya adsorbsi BR jenis aliran turbulen untuk besar 10 mesh, masingmasing 42,16 \% dan 42,76\%. Sedangkan untuk besar butir 20 mesh ada perbedaan daya adsorbsi yang signifikan antara BR jenis aliran laminar dengan BR jenis aliran turbulen, yaitu 33,88 \% untuk BR jenis aliran laminar dan 26,08 $\%$ untuk BR jenis aliran turbulen. Perbedaan ini terjadi oleh karena pada jenis aliran turbulen, terjadi turbulensi antara emisi gas dengan butiran zeolit, sehingga waktu dan jumlah luas permukaan persentuhan antara emisi gas buang dengan butiran zeolit lebih besar. Keadaan ini menyebabkan kemungkinan terjadinya adsorbsi dan oksidasi gas CO. Gas CO teroksidasi 
menjadi gas $\mathrm{CO}_{2}$, sehingga dideteksi terjadi penurunan konsentrasi gas $\mathrm{CO}$ di dalam emisi gas buang. Hal ini dapat terjadi karena zeolit alam selain berfungsi sebagai adsorben juga dapat berfungsi sebagai katalis, (Xiongfu, dkk., 2004). Dari gambar 6 dapat dilihat secara kualitatif bahwa daya adsorbsi BR jenis aliran laminar relatif sama dengan daya adsorbsi BR jenis aliran turbulen untuk besar butir 10 mesh. Sedangkan pada gambar 7 juga dapat dilihat secara kualitatif bahwa ada perbedaan daya adsorbsi BR jenis aliran laminar dengan daya absorbsi BR jenis aliran turbulen untuk besar butir 20 mesh. Daya adsorbsi BR jenis laminar lebih dominan.

Cara yang sama dengan gas $\mathrm{CO}$ data-data pengujian untuk emisi gas $\mathrm{CO}_{2}$ diperlihatkan pada tabel 2. Pada tabel 2 disajikan persentase daya adsorbsi BR jenis aliran laminar dan aliran turbulen terhadap gas $\mathrm{CO}_{2}$, baik untuk besar butir zeolit 10 mesh dan maupun untuk besar butir 20 mesh. Kemudian data-data ini disajikan dalam bentuk kurva seperti ditunjukkan pada gambar 8 dan gambar 9. Pada tabel 2 ada perbedaan antara nilai rerata daya adsorbsi BR jenis aliran laminar dan nilai rerata daya adsorbsi BR jenis aliran turbulen, baik untuk pemakaian besar butir zeolit 10 mesh maupun untuk besar butir 20 mesh. Nilai rerata daya absorbsi BR dengan besar butir zeolit 10 mesh adalah 47,76\% dan 42,28 \%, masing-masing untuk BR jenis aliran laminar dan untuk BR jenis aliran turbulen. Sedangkan nilai rerata daya absorbsi untuk besar butir zeolit 20 mesh adalah 33,28 \% dan 22,36 \%, masing-masing untuk BR jenis aliran laminar maupun BR jenis aliran turbulen.
Tabel 1. Daya adsorpsi BR zeolit untuk gas CO (\%) dengan variasi besar butir

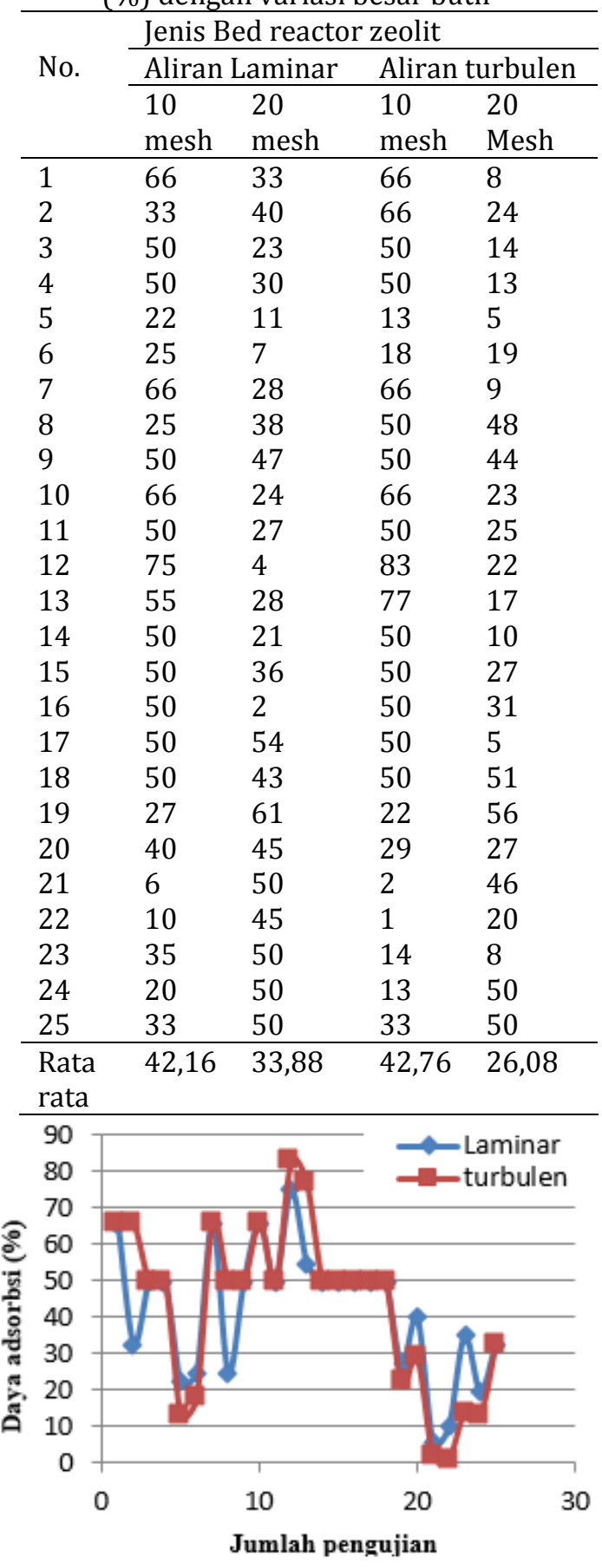

Gambar 6. Kurva daya adsorbsi untuk Gas CO Besar butir zeolit 10 mesh 
Siregar, A., Rancangan Media Adsorbsi Zeolit Alam Sebagai Adsorben Emisi Gas Mesin Otomotif

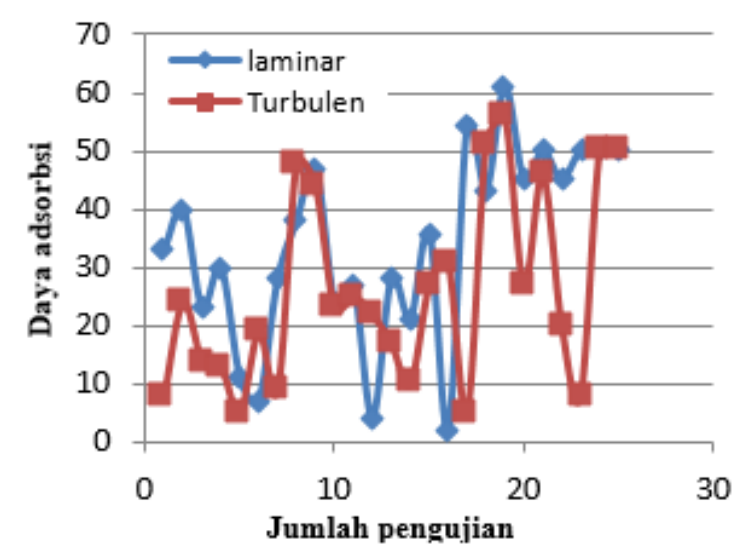

Gambar 7. Kurva daya adsorbsi untuk Gas CO Besar butir zeolit 20 mesh

Tabel 2. Daya adsorbsi BR zeolit Untuk gas CO2 (\%) dengan variasi besar butir

\begin{tabular}{|c|c|c|c|c|}
\hline \multirow{4}{*}{ No. } & \multicolumn{4}{|c|}{ Jenis bed reactor zeolit } \\
\hline & \multicolumn{2}{|c|}{ Aliran Laminar } & \multicolumn{2}{|c|}{ Aliran turbulen } \\
\hline & 10 & 20 & 10 & 20 \\
\hline & mesh & esh & mesh & Mesh \\
\hline 1 & 50 & 4 & 53 & 5 \\
\hline 2 & 51 & 67 & 51 & 2 \\
\hline 3 & 54 & 39 & 59 & 23 \\
\hline 4 & 48 & 38 & 41 & 23 \\
\hline 5 & 39 & 43 & 27 & 18 \\
\hline 6 & 79 & 36 & 77 & 17 \\
\hline 7 & 77 & 44 & 76 & 30 \\
\hline 8 & 24 & 47 & 14 & 43 \\
\hline 9 & 25 & 45 & 20 & 41 \\
\hline 10 & 49 & 3 & 41 & 5 \\
\hline 11 & 34 & 4 & 40 & 4 \\
\hline 12 & 46 & 2 & 49 & 1 \\
\hline 13 & 45 & 5 & 47 & 8 \\
\hline 14 & 43 & 54 & 45 & 51 \\
\hline 15 & 45 & 53 & 47 & 51 \\
\hline 16 & 49 & 46 & 49 & 49 \\
\hline 17 & 57 & 51 & 27 & 52 \\
\hline 18 & 56 & 45 & 27 & 39 \\
\hline 19 & 58 & 48 & 41 & 35 \\
\hline 20 & 67 & 8 & 67 & 5 \\
\hline 21 & 66 & 21 & 67 & 2 \\
\hline 22 & 41 & 8 & 37 & 3 \\
\hline 23 & 43 & 52 & 39 & 9 \\
\hline 24 & 20 & 35 & 12 & 8 \\
\hline 25 & 28 & 34 & 4 & 35 \\
\hline $\begin{array}{l}\text { Rata- } \\
\text { rata }\end{array}$ & 47,76 & 33,28 & 42,28 & 22,36 \\
\hline
\end{tabular}

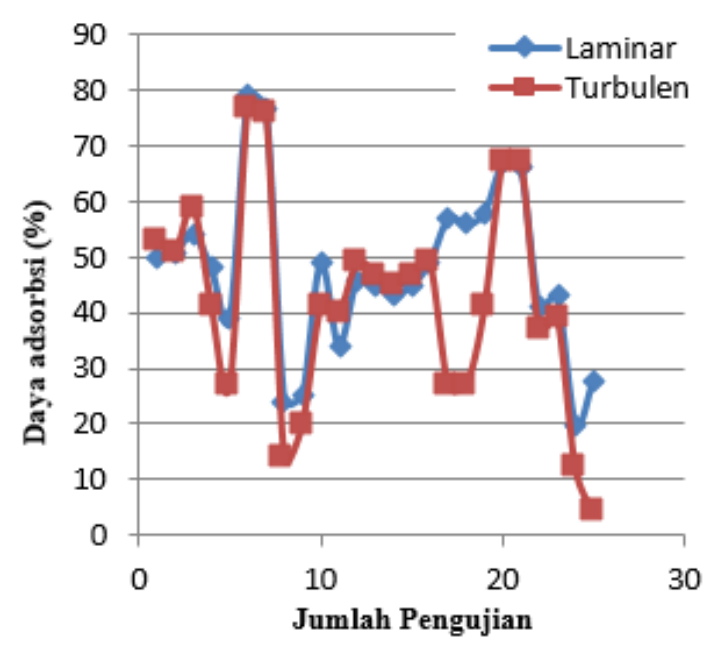

Gambar 8. Kurva daya adsorbsi BR terhadap gas $\mathrm{CO}_{2}$ untuk 10 mesh

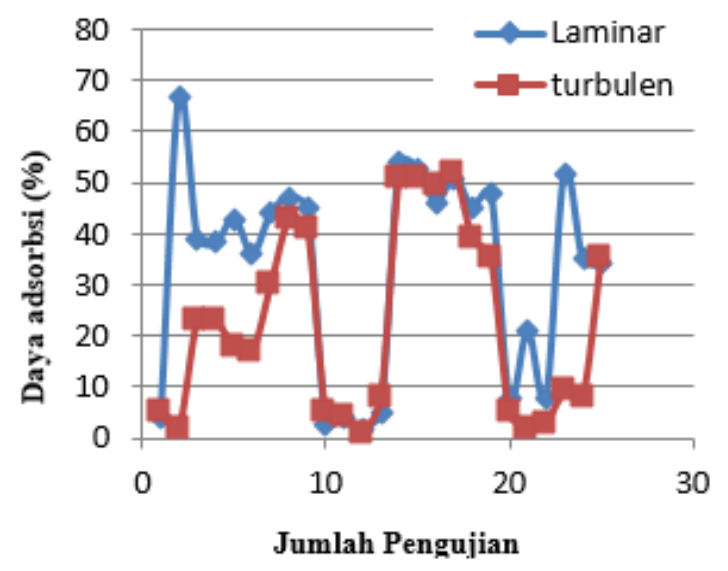

Gambar 9. Kurva daya adsorbsi BR terhadap gas $\mathrm{CO}_{2}$ untuk 20 mesh

Perbedaan daya adsobsi ini dapat dijelaskan berikut ini. Pertama dijelaskan perbedaan daya adsorbsi akibat variasi besar butir zeolit. Nilai rerata daya adsobsi untuk besar butir 10 mesh dan 20 mesh untuk BR jenis aliran laminar masing-masing 47,76 \% dan $33,28 \%$. Perbedaan ini dapat terjadi disebabkan oleh faktor bentuk geometris dari BR itu sendiri. Faktor bentuk geometris BR terutama ukuran besar lubang-lubang jalan masuk emisi gas buang ke rongga bola-bola berjaring (berjala-jala). Oleh karena posisi bolabola berjaring berada di dalam pipa 
aliran emisi gas dan kawat jala-jala 10 mesh digunakan pada bola berongga untuk butiran zeolit 10 mesh, dan kawat jaring 20 mesh digunakan pada bola berongga untuk butiran zeolit 20 mesh. Dari variasi jenis kawat jala-jala ini dapat dipahami bahwa lubang-lubang kawat berjaring 10 mesh lebih besar daripada lubang-lubang kawat jala-jala 20 mesh. Hal ini berarti emisi gas buang akan masuk lebih banyak ke rongga bola jaring yang berkawat jaring 10 mesh dibandingkan dengan yang masuk ke rongga bola berkawat jaring 20 mesh. Begitu juga halnya jumlah gas $\mathrm{CO}_{2}$ yang masuk ke rongga bola berjaring sebanding dengan jumlah emisi gas buang yang masuk ke rongga bola berjaring. Oleh karena itu jumlah gas $\mathrm{CO}_{2}$ akan lebih banyak teradsorbsi oleh BR dengan butiran zeolit 10 mesh daripada BR dengan butiran zeolit 20 mesh. Hal ini dapat terjadi oleh karena jumlah permukaan sentuh antara butiran zeolit dengan polutan gas $\mathrm{CO}_{2}$, (Lalang, dkk., 2012).

Tabel 3. Daya adsorbsi BR zeolit untuk gas HC

\begin{tabular}{lllll}
\multicolumn{5}{c}{ (\%) dengan variasi besar butir } \\
\hline \multirow{4}{*}{$\begin{array}{l}\text { Jenis bed reactor zeolit } \\
\text { uji }\end{array}$} & \multicolumn{3}{l}{ Aliran } \\
\cline { 2 - 5 } & Laminar & Aliran turbulen \\
& 10 & 20 & 10 & 20 \\
& mesh & mesh & mesh & Mesh \\
\hline 1 & 35 & 24 & 7 & 12 \\
2 & 52 & 19 & 47 & 9 \\
3 & 29 & 5 & 62 & 23 \\
4 & 58 & 36 & 79 & 57 \\
5 & 52 & 30 & 81 & 17 \\
6 & 59 & 38 & 66 & 20 \\
7 & 64 & 41 & 64 & 54 \\
8 & 23 & 18 & 15 & 9 \\
9 & 30 & 37 & 20 & 39 \\
10 & 12 & 18 & 14 & 22 \\
11 & 16 & 23 & 22 & 24 \\
12 & 48 & 27 & 23 & 24 \\
13 & 36 & 8 & 20 & 72 \\
14 & 38 & 5 & 10 & 41
\end{tabular}

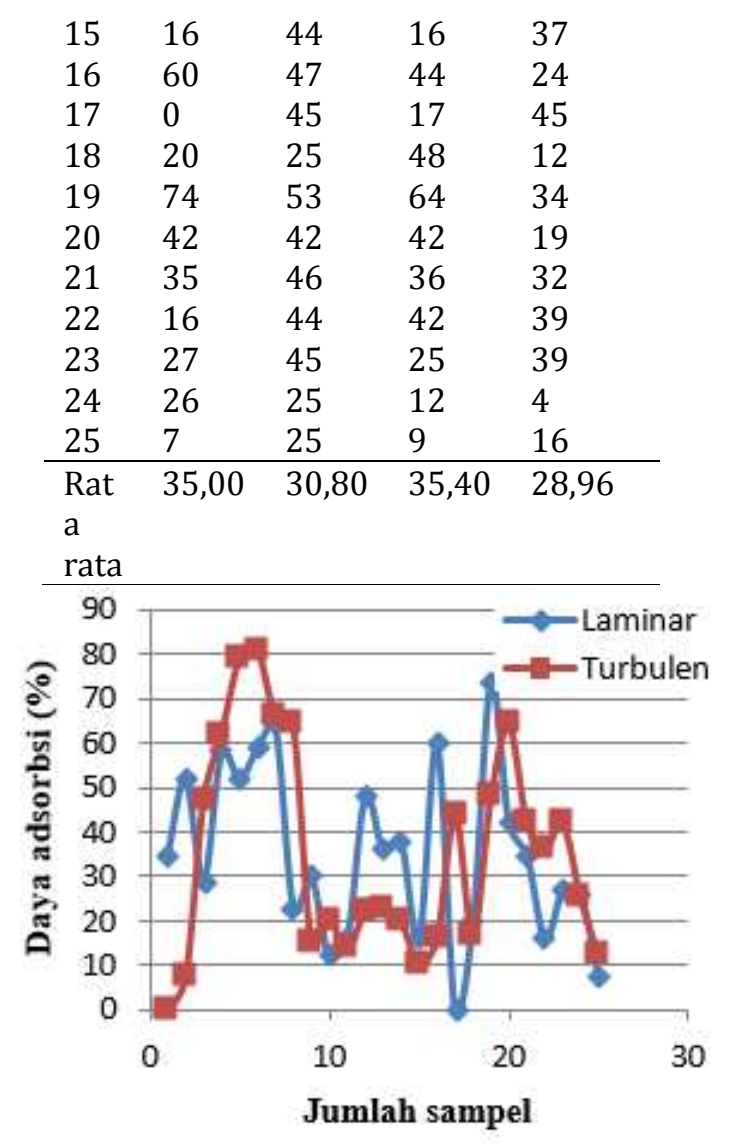

Gambar 10. Kurva daya adsorbsi gas HC besar butir 10 mesh

Dari gambar 8 dapat dilihat secara kualitatif bahwa daya adsorbsi BR jenis aliran laminar relatif sama dengan daya adsorbsi BR jenis aliran turbulen untuk besar butir 10 mesh. Sedangkan pada gambar 9 juga dapat dilihat secara kualitatif bahwa ada perbedaan yang kontras daya adsorbsi BR jenis aliran laminar dengan daya absorbsi BR jenis aliran turbulen untuk besar butir 20 mesh. Daya adsorbsi BR jenis laminar lebih dominan daripada daya adsorbsi BR jenis turbulen.

Cara yang sama dengan gas CO dan gas $\mathrm{CO}_{2}$, daya adsorbsi polutan emisi gas buang HC diperlihatkan pada tabel 3 . Pada tabel 3 disajikan persentase daya adsorbsi BR jenis aliran laminar dan aliran turbulen terhadap gas HC, baik untuk besar butir zeolit 10 mesh dan 
maupun untuk 20 mesh. Kemudian datadata ini disajikan dalam bentuk kurva seperti ditunjukkan pada gambar 10 dan gambar 11. Dari tabel 3 dapat dilihat bahwa nilai rerata daya adsorbsi BR jenis aliran laminar relatif sama dengan nilai rerata daya adsorbsi BR jenis aliran turbulen untuk besar 10 mesh, masingmasing 35,00 \% dan 35,40 \%. Sedangkan untuk besar butir 20 mesh tidak ada perbedaan yang signifikan daya adsorbsi antara BR jenis aliran laminar dengan BR jenis aliran turbulen, yaitu 30,80 \% untuk BR jenis aliran laminar dan 28,96 $\%$ untuk BR jenis aliran turbulen. Dari tabel 3 dapat dilihat perbedaan nilai rerata daya adsorbsi terjadi pada data variasi besar butir zeolit. Keadaan ini ekivalen dengan daya adsorsi BR terhadap gas $\mathrm{CO}_{2}$. (tabel 2). Oleh karena itu dapat dinyatakan perbedaan daya ini disebabkan oleh faktor bentuk geometris dari BR itu sendiri. Faktor bentuk geometris BR terutama ukuran besar lubang-lubang jalan masuk emisi gas buang ke rongga bola-bola berjaring (berjala-jala). Kawat jala-jala (jaring) 10 mesh digunakan pada bola berongga untuk butiran zeolit 10 mesh, dan kawat jaring 20 mesh digunakan pada bola berongga untuk butiran zeolit 20 mesh. Dari variasi jenis kawat jala-jala ini dapat dipahami bahwa lubang-lubang kawat berjaring 10 mesh lebih besar daripada lubang-lubang kawat jala-jala 20 mesh. Hal ini berarti emisi gas buang akan masuk lebih banyak ke rongga bola jaring yang berkawat jaring 10 mesh dibandingkan dengan yang masuk ke rongga bola berkawat jaring 20 mesh. Begitu juga halnya jumlah gas HC yang masuk ke rongga bola berjaring sebanding dengan jumlah emisi gas buang yang masuk ke rongga bola berjaring. Oleh karena itu jumlah gas HC akan lebih banyak teradsorbsi oleh BR dengan butiran zeolit 10 mesh daripada BR dengan butiran zeolit 20 mesh. Hal ini dapat terjadi oleh karena jumlah permukaan sentuh antara butiran zeolit dengan polutan gas HC, (Lalang, dkk., 2012).

Dari gambar 10 dapat dilihat secara kualitatif bahwa daya adsorbsi BR jenis aliran laminar relatif sama dengan daya adsorbsi BR jenis aliran turbulen untuk besar butir 10 mesh. Sedangkan pada gambar 11 juga dapat dilihat secara kualitatif bahwa ada perbedaan daya adsorbsi BR jenis aliran laminar dengan daya absorbsi BR jenis aliran turbulen untuk besar butir 20 mesh. Daya adsorbsi BR jenis laminar lebih dominan.

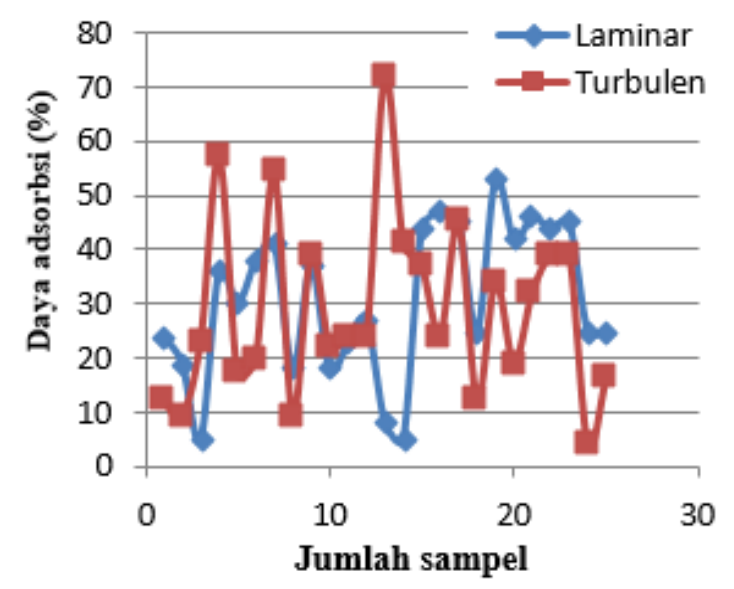

Gambar 11. Kurva daya adsorbsi gas HC besar butir 20 mesh

\section{KESIMPULAN}

Telah dirancang alat media adsorbsi zeolit alam terhadap polutan emisi gas buang mesin otomotif. Alat media tersebut dinamai bed reactor (BR). Bentuk geometris BR terdiri dua jenis yaitu BR jenis aliran laminar dan 
jenis aliran turbulen. Alat media adsorbsi ini dapat menurunkan konsentrasi polutan emisi gas buang mesin otomotif sebagai berikut : Diperoleh nilai maksimum daya adsorbsi BR terhadap polutan gas $\mathrm{CO} \pm 42 \%$ untuk jenis aliran turbulen, gas $\mathrm{CO}_{2} \pm 47 \%$ untuk $\mathrm{BR}$ jenis aliran laminar, dan gas $\mathrm{HC} \pm 35,40 \%$ untuk aliran turbulen, masing-masing dengan besar butir 10 mesh.

\section{UCAPAN TERIMA KASIH}

Penelitian ini dapat terlaksana dengan baik berkat atas bantuan dan kerjasama dari berbagai pihak. Oleh karena itu pada kesempatan ini penulis mengucapkan terimakasih banyak kepada bapak Direktur pada Direktorat Riset dan Pengabdian Masyarakat, Direktorat Jenderal Penguatan riset dan Pengembangan, Kementerian Riset, Teknologi, dan Pendidikan Tinggi, yang telah membiayai penelitian ini melalui Hibah Kompetitif Penelitian. Kepada Dekan Fakultas Teknik UMA, serta Lembaga Penelitian dan Pengabdian kepada Masyarakat UMA yang telah memberikan dukungan penuh atas terlaksananya kegiatan penelitian ini. Kepada bapak Kepala Dinas Perhubungan Pemerintah Provinsi Sumatera Utara, yang telah memberikan bantuan alat uji emisi gas buang mesin kenderaan roda empat, hingga selesainya pengambilan data penelitian ini.

\section{REFERENCES}

Hasibuan, A., R., 2012, Modifikasi Zeolit Alam dengan $\mathrm{TiO}_{2}$ untuk Mereduksi Emisi Gas Buang Kenderaan Bermotor, Skripsi, Program Studi Teknik Kimia, Fakultas Teknik, Universitas Indonesia.
Ismiyati, Marlita, D., dan Saidah D., 2014, Pencemaran Udara Akibat Emisi Gas Buang Kenderaan Bermotor, Jurnal Manajemen Transportasi \& Logistik, Vol. o1 No. 03.

Kusdarto, 2008, Potensi Zeolit di Indonesia, Jurnal Zeolit Indonesia, Departemen Energi Dan Sumber Daya Mineral Vol. 7 No. 2.

Khaidir, Setyaningsih, D., dan Haerudin, H., 2009, Modifikasi Zeolit Alam Sebagai Material Molekular Sieve pada Proses Dehidrasi Bioetanol, Jurnal Zeolit Indonesia, Departemen TIP FATETA IPB, Vol. 8, No.2.

Lalang Budi Rianto, Suci Amalia, Susi Nurul Khalifah, 2012, Pengaruh Impregnasi Logam Titanium pada Zeolit Alam Malang Terhadap Luas Permukaan Zeolit, Alchemy, Vol. 2 No. 1, hal 58-67.

Pardoyo, Listiana, dan Darmawan, A., 2009, Pengaruh Perlakuan $\mathrm{HCl}$ pada Kristalinitas dan Kemampuan Absorbsi Zeolit Alam Terhadap ion $\mathrm{Ca}+2$, Jurnal Sains \& Matematika, Vol. 17, No. 2.

Sarno, H., 1983, Endapan Zeolite, Penggunaan dan Sebarannya di Indonesia, Direktorat Sumber Daya Mineral, Departemen Pertambangan dan Energi, Bandung.

Suraputra, R., 2011, Adsorpsi Gas Karbon Monoksida (CO) dan Perjernihan Asap Kebakaran Menggunakan Zeolit Alam Lampung Termodifikasi TiO2, Skripsi, Departemen Teknik Kimia, Fakultas Teknik, Universitas Indonesia.

Tsishvili, B., V., 1992, Natural Zeolite, Institute of Physical and Organic Chemistry Academiy of sciences of Georgia, First Edition.

Venkatesh, V., Jaikumar, M., Mylaudy, and Rajadurai, S., 2016, CO Capture by Using Modified ZMS- 5 Zeolite in Diesel Powered Vehicle, IOSR Journal of Mechanical and Civil Engineering (IOSR-JMCE) e-ISSN: 2278-1684, Volume 13.

Yuliusman, Widodo, W., P., Yulianto, S., N., dan Yuda, P., 2010, Preparasi Zeolit Alam Lampung dengan Larutan $\mathrm{HF}, \mathrm{HCl}$, dan Kalsinasi untuk Adsorpsi CO, Seminar Rekayasa Kimia dan Proses, Jurusan Teknik Kimia Fakultas Teknik, Universitas Diponegoro, Semarang.

Yamliha, A., Argo, D., B., dan Nugroho, A., W., 2013, Pengaruh Ukuran Zeolit Terhadap Penyerapan Karbon dioksida $\left(\mathrm{CO}_{2}\right)$ pada aliran biogas, Jurnal Bioproses Komoditas Tropis, Vol.1, No. 2. 